\title{
RESPONSE OF RICE PLANT GROWN ON NEWLY RECLAIMED SALINE SOIL TO A MIXTURE OF CHELATED FE, MN AND ZN APPLIED BY DIFFERENT METHOD AND RATES
}

Shaban, K. A. H. ; Manal A. Attia and Awatef A. Mahmoud

Soils, Water and Environ. Res. Inst., Agric. Res. Centre (A.R.C.) Giza, (Egypt).

\begin{abstract}
Two field experiments were carried out on a newly reclaimed saline soil during two successive summer seasons (2007 and 2008) at Sahl El-Hossinia, El-Sharkia Governorate, Egypt .The aim is to test the response of rice to applied chelated Fe, $\mathrm{Mn}$ and $\mathrm{Zn}$ in the form of EDTA. Application comprised three different methods; coating, soaking and foliar spray.In the coating method application of each nutrient was at a rate of $0.1,0.2,0.3 \mathrm{~g} / \mathrm{Kg}$ grains. For soaking and foliar application, these elements were applied at $150,250,350 \mathrm{mg} / \mathrm{Kg}$ grains. Soaking was performed in $100 \mathrm{~L}$ and lasted for 24 hours. However, these nutrients were sprayed at a rate of $200 \mathrm{~L} / \mathrm{fed}$. The yield and its components as well as the content and the uptake of macro and micronutrients of rice grain (Oryza- Sativa) Cv. Giza 178 were appraised. Results revealed that applying micronutrients by soaking method was very effective on grain yield compared to the other applied treatments. The percentages increase ranged from 142.23 to 178.81 , while in coating treatment they ranged from 85.8 to 117.42and in foliar treatments from 89.37 to 112.08 over control; as an average of both seasons. Elevating the rate of applied chelated compounds caused significant increases in the straw and grain yields, while 1000 grain weight was not significantly affected. The results disclosed that phosphorus content in straw and grain in response to the studied treatments gave a significant increase. Nonetheless, $\mathrm{N}$ and $\mathrm{K}$ contents showed no significant response. As for the concentrations of $\mathrm{Fe}, \mathrm{Mn}$ and $\mathrm{Zn}$ in the straw there was a significant effect due to both methods and rates of application. But, for the grains they had significant effect in the case of $\mathrm{Zn}$ application only. The uptake of N, P, Fe and $\mathrm{Zn}$ in straw besides N, P, Mn and $\mathrm{Zn}$ in grains were significant increase by application of either methods or rates of the mixture chelated micronutrients. Data revealed that the increment response for the methods of application of micronutrients could be arranged as follows: soaking >coating $>$ foliar. Soaking at the rate of $350 \mathrm{mg} / \mathrm{Kg}^{-1}$ gave the best results for the yield of rice and its components .
\end{abstract}

Keywords: Micronutrients (EDTA), saline soil, rice productivity, soaking, coating, foliar.

\section{INTRODUCTION}

Micronutrient requirements for plant, animal, and human are rather low. However, they are essential for vital cell functions. Deficiency of these elements can greatly disturb plant yield and quality, and the health of both domestic animals and humans (Malakouti, 2007). Nonetheless, nutrients absorption by plants is substationally affected in saline soil. Alam et al. (2001) noted that salinity affects the growth of rice in varying degrees at all stages of its life cycle starting from germination up to maturity. These effects may vary depending on the stage of plant development. Several studies 
indicated that rice is tolerant during germination and becomes very sensitive during early seedling stage. Thereafter, gains tolerance during vegetative growth but again becomes sensitive during pollination and fertilization. However, it increasingly becomes more tolerant at maturity stage. FAO (1995) confirmed that the majority of salt-affected soils in Egypt are located in the Northern-Central part of the Nile Delta and on its Eastern and Western sides. Fifty five percent of the cultivated lands of Northern Delta region are salt-affected. However only twenty per cent of the soils of Southern Delta and middle Egypt region besides twenty five percent located in the Upper Egypt region are salt-affected soils. The Southern part of El-Hussinia plain, Sharkia Governorate, Egypt covering an area of about $141.6 \mathrm{Km}^{2}$. Imtiaz et al. (2003) stated that lack of just one micronutrient can greatly reduce plant yield. Adequate nutrition of plant with micronutrients depends on many factors among them is the ability of soil to supply these nutrients, rate of nutrients absorption by the plants, distribution of nutrients to function sites and nutrients mobility within the plant. Anand (1993) studied the effect of three levels of Fe $(0.2,0.4,0.6 \mathrm{mg} / \mathrm{Kg})$ and two levels of $\mathrm{Zn}(2.5 \mathrm{Kg}$ and $10 \mathrm{Kg} / \mathrm{Fed})$ and their combinations on the growth and yield of rice grown on a zinc deficient sodic soil. Application of $\mathrm{Zn}$, had significantly enhanced the yield of rice and available $\mathrm{Zn}$ in soil and plant $\mathrm{Zn}$ content; irrespective of $\mathrm{Fe}$ application. Fe application showed a significant improvement in available soil and plant content of $\mathrm{Fe}$ and $\mathrm{Mn}$. But, it significantly, decreased $\mathrm{Zn}$ content of the crop. He suggested that benefits of Fe application to rice in sodic soils can only be obtained if it is applied along with Zn. El-Bordiny and El-Dewiny (2008) showed that micronutrients availability are governed with $\mathrm{pH}, \mathrm{OM}$, clay content, CEC and ESP. Calcium carbonate and gypsum contents are negatively correlated with different micronutrients. Malakouti (2000) found that the addition of each micronutrient $(\mathrm{Fe}, \mathrm{Zn}, \mathrm{Cu}$, and $\mathrm{B})$ or a combination of $\mathrm{Fe}+\mathrm{Zn}+\mathrm{Cu}+\mathrm{B}$ to NPK fertilizer augmented the grain yield of wheat. The highest yield was obtained as all the micronutrients were added along with NPK fertilizers. El-Fouly et al. (2001) noted that application of micronutrients to faba bean and/or wheat showed positive effects on growth and nutrients uptake either before or after the salinlization treatment. They concluded that foliar application of micronutrients could enhance salinity tolerance. Sairam and Tyagi (2004) suggested that foliar spraying with micronutrients, especially $\mathrm{Fe}, \mathrm{Mn}$ and $\mathrm{Zn}$, increased yield crops and mineral contents of many plant types under saline stress conditions.

The aim of this work is to study the response of grain yield of rice crop grown on newly reclaimed saline soil to different application methods and rates of $\mathrm{Fe}, \mathrm{Mn}$ and $\mathrm{Zn}$ chelates.

\section{MATERIALS AND METHODS}

Two field experiments were conducted in two successive summer seasons 2007 and 2008 at the private farm of El-Radwan village of Sahl ElHossinia, El-Sharkia Governorate, to study, which of micronutrients methods of application namely coating, soaking and foliar and their rates is more efficient in increasing rice yield. 
Soil samples at $0-30 \mathrm{~cm}$ depth were collected to determine some physical and chemical properties in a composite sample. Soil samples were subjected to the determination of the available $\mathrm{N}, \mathrm{P}$ and $\mathrm{K}$ as outlined by Black et al. (1965). Available $\mathrm{Fe}, \mathrm{Mn}$ and $\mathrm{Zn}$ in soil were extracted as described by Lindsay and Norvell (1978) and determined by the aid of Atomic Absorption model GBC 932 (Table 1).

The irrigation was practiced through El- Salam canal (Agriculture drainage water mixed with fresh Nile water 1:1). Water irrigation samples were collected from the three sources in both seasons to determine some of their chemical properties at four periods during rice planting, i.e., May, June, August and September. Salinity of the water EC $\left(\mathrm{dSm}^{-1}\right)$ and soil $\mathrm{pH}$ were determined (Table 2).

Table (1): Some soil characteristics for the experimental location

\begin{tabular}{|c|c|c|c|c|c|c|c|c|c|}
\hline Location & $\begin{array}{l}\text { Coarse } \\
\text { sand } \\
\text { (\%) }\end{array}$ & $\begin{array}{l}\text { Fine } \\
\text { sand } \\
(\%)\end{array}$ & $\begin{array}{l}\text { Silt } \\
(\%)\end{array}$ & \multicolumn{2}{|c|}{$\begin{array}{c}\text { Clay } \\
(\%)\end{array}$} & Texture & \multicolumn{2}{|c|}{$\begin{array}{l}\text { O.M } \\
(\%)\end{array}$} & $\begin{array}{c}\mathrm{CaCO}_{3} \\
(\%)\end{array}$ \\
\hline \multirow{7}{*}{$\begin{array}{l}\text { El- } \\
\text { Radwan } \\
\text { village }\end{array}$} & 2.96 & 66.04 & 12.73 & & & Clay & 0.6 & & 10 \\
\hline & \multirow{2}{*}{$\begin{array}{c}\text { pH } \\
(1: 2.5)\end{array}$} & \multirow{2}{*}{$\begin{array}{c}E C \\
\text { (dS/m) }\end{array}$} & \multicolumn{4}{|c|}{ Cations (meq/l) } & \multicolumn{3}{|c|}{ Anions (meq/l) } \\
\hline & & & $\mathrm{Ca}^{++}$ & $\mathrm{Mg}^{++}$ & $\mathrm{Na}^{+}$ & $\mathrm{K}^{+}$ & \multicolumn{2}{|c|}{$\mathrm{HCO}_{3}^{-} \mathrm{Cl}^{-}$} & $\mathrm{SO}_{4}^{-1}$ \\
\hline & 8.29 & 17.36 & 9.23 & 14.99 & 148 & 0.93 & 9.72 & 120 & 43.43 \\
\hline & \multicolumn{3}{|c|}{$\begin{array}{c}\text { Available } \\
\text { macronutrients } \\
\left(\mathrm{mg}^{\prime} \mathrm{kg}^{-1}\right)\end{array}$} & \multicolumn{6}{|c|}{$\begin{array}{c}\text { Available } \\
\text { micronutrients } \\
\left(\mathrm{mg} / \mathrm{kg}^{-1}\right)\end{array}$} \\
\hline & $\mathbf{N}$ & $\mathbf{P}$ & $\mathrm{K}$ & $\mathrm{Fe}$ & Mn & $\mathrm{Zn}$ & & $\mathrm{Cu}$ & \\
\hline & 44 & 5.39 & 196 & 2.36 & 1.87 & 0.53 & & 0.08 & \\
\hline
\end{tabular}

Table (2): Some Chemical properties of irrigation water at El-Salam canal during the two growing season for rice plant

\begin{tabular}{|l|c|c|c|c|c|}
\hline \multirow{2}{*}{ Soil properties } & \multirow{3}{*}{ Season } & \multicolumn{4}{|c|}{ El-Salam canal } \\
\cline { 3 - 6 } & & \multicolumn{4}{|c|}{ Periods of irrigation } \\
\cline { 3 - 6 } & & 1 & 2 & 3 & 4 \\
\cline { 3 - 6 } EC $\left(\mathrm{dSm}^{-1}\right)$ & $1^{\text {st }}$ & 1.06 & 1.14 & 1.57 & 1.01 \\
\hline \multirow{2}{*}{$\mathrm{pH}$} & $2^{\text {nd }}$ & 1.04 & 1.26 & 1.42 & 1.08 \\
\hline & $1^{\text {st }}$ & 8.02 & 8.12 & 8.09 & 7.96 \\
\cline { 2 - 6 } & $2^{\text {1- May }}$ & 8.09 & 8.06 & 8.13 & 7.99 \\
\hline
\end{tabular}

The experimental soil layout was subjected to some pretreatments processes as follows: (a) levelling the soil surface by using lazar technique. (b) Deep sub-soiling plough. (c) Establishment of filed drains at a distance of $10 \mathrm{~m}$ between each of two drains and a deep of $90 \mathrm{~cm}$ at drain beginning, their drainage water flow towards the main collectors was of $2 \mathrm{~m}$ in depth and (d) establishment of an irrigation canal in the middle part of the experimental pilot unit.

The micronutrients were applied as a mixture of even ratio of chelated $\mathrm{Fe}, \mathrm{Mn}$ and $\mathrm{Zn}$ in the form of EDTA compound; Fe -EDTA ( $6 \% \mathrm{Fe}) ; \mathrm{Mn}-$ EDTA (13\% Mn) and Zn -EDTA (12\%Zn). Rice grains were soaked for 24 hours in a mixture of the previously mentioned micronutrients. Rice grains 
needed for coating due to one feddan were $(80 \mathrm{Kg})$. Foliar spray solution from the mixture of the chelated compounds was applied at a rate of $200 \mathrm{~L} / \mathrm{fed}$. The experimental treatments were as the following:

1- Control (without micronutrients).

2- Grains coating at the rate of $(0.1,0.2$ and $0.3 \mathrm{~g} / \mathrm{kg}$ grain) for each nutrient.

3- Grains soaking $(150,250$ and $350 \mathrm{mg} / \mathrm{L})$ for each nutrient were lasted for 24 hour in a volume of 100 liters.

4- Foliar spraying $(150,250$ and $350 \mathrm{mg} / \mathrm{L})$ for each nutrient solution was used at the rate of $200 \mathrm{~L} / \mathrm{fed}$ added three times; 21,45 and 60 days from rice sowing.

Experimental fields of both seasons were prepared and divided into plots $\left(50 \mathrm{~m}^{2}\right)$ and each treatment was replicated three times in a randomized complete block design. All plots received basal dressing of $\mathrm{N}, \mathrm{P}$ and $\mathrm{K}$. $100 \mathrm{~kg} \mathrm{~N} / \mathrm{fed}$ from urea $(46 \% \mathrm{~N})$ were applied three times 21,35 and 50 day from planting. $200 \mathrm{~kg} /$ fed from calcium super phosphate $\left(15.5 \% \mathrm{P}_{2} \mathrm{O}_{5}\right)$ were applied during soil tillage before rice sowing. Potassium sulphate $\left(48 \% \mathrm{~K}_{2} \mathrm{O}\right)$ was applied at a rate of $100 \mathrm{~kg} / \mathrm{fed}$ in two split equal doses once before rice sowing and later after 35 days from sowing. Sowing of rice grains was carried out at the $1^{\text {st }}$ and $5^{\text {th }}$ of May in both seasons.

At harvest, grain and straw yields were recorded in ton/fed. Grain samples from each treatment were taken for chemical analysis. Grain and straw samples were wet digested using $\mathrm{H}_{2} \mathrm{SO}_{4}$ and $\mathrm{HClO}_{4}$ acid mixture1:1(v/v). The digest was then used to determine $\mathrm{N}, \mathrm{P}$ and $\mathrm{K}$ content of both rice grains and straw as described by Chapman and Pratt (1961).As well as $\mathrm{Fe}, \mathrm{Mn}$ and $\mathrm{Zn}$ concentrations were determined using Atomic Absorption Spectrophotometer (GBC 932).

\section{RESULTS AND DISCUSSION}

\section{Rice yield and yield components:}

Data illustrated in Table (3) show straw and grain yield and $1000-$ grain weight of rice plant. Application of various methods and different rates of the mixture of chelated micronutrients compound showed that all treatments significantly augmented rice straw and grain yields. Nonetheless, soaking and foliar methods exhibited higher values compared with coating method in both seasons. Moreover, results indicated that increasing the rate of the mixture chelated micronutrients $(\mathrm{Fe}, \mathrm{Mn}$ and $\mathrm{Zn}$ ) played a substantial role in raising the yield of straw and grain. Results also, revealed that there was no significant increase in 1000-grain weight due to the application of various methods and different rates of the mixture of chelated micronutrients compound. The relative increases for straw in ${ }^{\text {st }}$ season were $47.98,55.61$ and $56.68 \%$ but they were $41.85,49.61$ and $50.27 \%$ in $2^{\text {nd }}$ season due the rice grains coated with $0.1,0.2$ and $0.3 \mathrm{~g}$ of the mixture of chelating micronutrients compound; compared to control. However, the percentage increases of grain yield were $96.73,114.55$ and 117.42 in $1^{\text {st }}$ and 85.80, 94.19 and 96.16 in $2^{\text {nd }}$ season due to the same corresponding order of coating treatment. These results resemble those reported by Ghaly et al. 
(1992) on wheat. They found that the coated wheat seeds with chelated Zn, $\mathrm{Fe}$ and $\mathrm{Mn}$ increased the grain and straw yields of wheat. The current results indicated that the corresponding relative increases at soaking method were $96.72,105.29$, and $107.31 \%$ in $1^{\text {st }}$ and $88.39,96.51$ and $125.49 \%$ in $2^{\text {nd }}$ season for straw against $164.75,171.18$ and $178.81 \%$ in $1^{\text {st }}$ and 142.23 , 158.21 and $160.71 \%$ in $2^{\text {nd }}$ season for grain due to soaking at the rates of 150,250 and $350 \mathrm{mg} / \mathrm{Kg}^{-1}$. As well as, the relative increases at foliar application method were $49.37,61.60$ and $68.16 \%$ in $1^{\text {st }}$ and $42.99,54.48$ and $62.96 \%$ in $2^{\text {nd }}$ season for straw while it were $104.46,110.89$ and $112.08 \%$ in $1^{\text {st }}$ and $89.38,91.61$ and $92.32 \%$ in $2^{\text {nd }}$ season at the same rates. In this respect, Ghaly et al.(1992), Amin et al. (1998) and Badr et al.(1998) demonstrated that significant yield increases could be obtained by treating wheat seeds with (Fe, Mn, $\mathrm{Zn}$ ) and a mixture of them was more effective than using any of them individually.

Table (3): Effect of some micronutrients applications on rice yield grown in two different seasons (2007-2008)

\begin{tabular}{|c|c|c|c|c|}
\hline Treatments & $\mathrm{Zn}+\mathrm{Mn}+\mathrm{Fe}$ & $\begin{array}{c}\text { Straw yield } \\
(\mathrm{Kg} / \mathrm{fed})\end{array}$ & Grain (Kg/fed) & $\begin{array}{c}\text { Weight of } \\
1000 \text { grains }(g)\end{array}$ \\
\hline \multicolumn{5}{|c|}{2007} \\
\hline control & & 1.586 & 1.010 & 22 \\
\hline \multirow{3}{*}{$\begin{array}{l}\text { Coating } \\
(\mathrm{g})\end{array}$} & 0.1 & 2.347 & 1.987 & 23 \\
\hline & 0.2 & 2.468 & 2.167 & 24 \\
\hline & 0.3 & 2.485 & 2.196 & 27 \\
\hline \multirow{3}{*}{$\begin{array}{l}\text { Soaking } \\
\left(\mathrm{mgKg}^{-1}\right)\end{array}$} & 150 & 3.120 & 2.674 & 29 \\
\hline & 250 & 3.256 & 2.739 & 31 \\
\hline & 350 & 3.288 & 2.816 & 33 \\
\hline \multirow{3}{*}{$\begin{array}{l}\text { Foliar } \\
\left(\mathrm{mgKg}^{-1}\right)\end{array}$} & 150 & 2.369 & 2.065 & 25 \\
\hline & 250 & 2.563 & 2.130 & 28 \\
\hline & 350 & 2.667 & 2.142 & 30 \\
\hline \multicolumn{5}{|c|}{2008} \\
\hline Control & & 1.663 & 1.120 & 25 \\
\hline \multirow{3}{*}{$\begin{array}{l}\text { Coating } \\
\text { (g) }\end{array}$} & 0.1 & 2.359 & 2.081 & 27 \\
\hline & 0.2 & 2.488 & 2.175 & 27 \\
\hline & 0.3 & 2.499 & 2.197 & 30 \\
\hline \multirow{3}{*}{$\begin{array}{l}\text { Soaking } \\
\left(\mathrm{mgKg}^{-1}\right)\end{array}$} & 150 & 3.133 & 2.713 & 32 \\
\hline & 250 & 3.268 & 2.892 & 33 \\
\hline & 350 & 3.750 & 2.920 & 34 \\
\hline \multirow{3}{*}{$\begin{array}{l}\text { Foliar } \\
\left(\mathrm{mgKg}^{-1}\right)\end{array}$} & 150 & 2.378 & 2.121 & 26 \\
\hline & 250 & 2.569 & 2.146 & 27 \\
\hline & 350 & 2.710 & 2.154 & 31 \\
\hline \multicolumn{2}{|c|}{ LSD \%5 Methods } & 0.094 & 0.093 & ns \\
\hline \multicolumn{2}{|c|}{ LSD\% 5 Rates } & 0.104 & 0.105 & ns \\
\hline
\end{tabular}

It is worthy to mention that the superiority of the applied methods can be ranked as soaking > foliar > coating, for straw yield in both seasons and soaking > coating > foliar for grain yield, in both seasons. This indicates the efficiency of applying micronutrients through grain soaking method to correct micronutrients deficiency rather than coating and/or foliar spray. These findings could be interpreted as soaking give chance to ample amounts of applied micronutrients to be absorbed by the grain; used later in the biological processes. This seems logic if comparing both soaking and coating. But, at 
the same time one may expect that foliar spray correct micronutrient deficiencies for plant started already to suffer. Monged and Mawardi (1978) and Korayem (1993) noted that soaking rice grain in zinc sulphate solution increased yield of grains due to increasing germination. Wang and Song (2005), improved seedling vigor and plant growth.

Micronutrients concentration in grain and straw of rice plant:

Data in Tables (4 \&5) show that the concentration of Fe, Mn and $\mathrm{Zn}$ significant increase in rice straw in both seasons due to the different applications and rates. As for grains, $\mathrm{Zn}$ concentration gave significant response but $\mathrm{Fe}$ and $\mathrm{Mn}$ concentrations did not show any significant results. Examining and interpretation of the results suggest that generally seed and fruits are the least plant organs to be affected by various fertilizer or agriculture practices treatments. Also, it seems that the results are in complete with rice plant requirements to zinc to accelerate the metabolic processes during the reproductive stage which run from panicle initiation to flowering and ripening phase and from flowering to maturity. The highest contents of $\mathrm{Fe}, \mathrm{Mn}$ and $\mathrm{Zn}$ in straw were 134,75 and $66 \mathrm{mg} / \mathrm{kg}^{-1}$ respectively, and 51,63 and $31 \mathrm{mg} / \mathrm{Kg}^{-1}$ for grain. Again, the obtained data disclosed the superiority of soaking compared to coating and/or foliar in elevating micronutrients content of both straw and grains. These results coincide with those obtained by Mohammad (2008) who found that the micronutrientenriched NPK fertilizers increase the concentration of micronutrients in rice grain.

Table (4): Macro-Micronutrients concentration in rice straw (2007 -2008)

\begin{tabular}{|c|c|c|c|c|c|c|c|}
\hline \multirow[t]{2}{*}{ Treatments } & \multirow[t]{2}{*}{$\mathrm{Zn}+\mathrm{Mn}+\mathrm{Fe}$} & \multicolumn{3}{|c|}{$\begin{array}{c}\text { Macronutrients } \\
(\%)\end{array}$} & \multicolumn{3}{|c|}{$\begin{array}{c}\text { Micronutrients } \\
\left.\text { (mgkg }{ }^{1}\right)\end{array}$} \\
\hline & & $\mathbf{N}$ & $\mathbf{P}$ & $\mathbf{K}$ & $\mathrm{Fe}$ & $\mathrm{Mn}$ & Zn \\
\hline \multicolumn{8}{|c|}{2007} \\
\hline Control & & 2.36 & 0.18 & 0.99 & 89 & 49 & 34 \\
\hline \multirow{3}{*}{$\begin{array}{l}\text { Coating } \\
(\mathrm{g})\end{array}$} & 0.1 & 2.58 & 0.25 & 1.08 & 93 & 53 & 41 \\
\hline & 0.2 & 2.63 & 0.29 & 1.13 & 98 & 57 & 44 \\
\hline & 0.3 & 2.67 & 0.31 & 1.17 & 111 & 62 & 46 \\
\hline \multirow{3}{*}{$\begin{array}{l}\text { Soaking } \\
\left(\mathrm{mgKg}^{-1}\right)\end{array}$} & 150 & 2.77 & 0.33 & 1.26 & 118 & 66 & 51 \\
\hline & 250 & 2.83 & 0.35 & 1.29 & 126 & 69 & 57 \\
\hline & 350 & 2.96 & 0.38 & 1.32 & 129 & 70 & 59 \\
\hline \multirow{3}{*}{$\begin{array}{l}\text { Foliar } \\
\left(\mathrm{mgKg}^{-1}\right)\end{array}$} & 150 & 2.46 & 0.23 & 1.05 & 96 & 53 & 43 \\
\hline & 250 & 2.54 & 0.28 & 1.16 & 98 & 55 & 47 \\
\hline & 350 & 2.59 & 0.30 & 1.18 & 104 & 56 & 49 \\
\hline \multicolumn{8}{|c|}{2008} \\
\hline Control & & 2.41 & 0.21 & 1.02 & 94 & 51 & 26 \\
\hline \multirow{3}{*}{$\begin{array}{l}\text { Coating } \\
(\mathrm{g})\end{array}$} & 0.1 & 2.61 & 0.28 & 1.12 & 99 & 55 & 44 \\
\hline & 0.2 & 2.67 & 0.32 & 1.15 & 107 & 60 & 51 \\
\hline & 0.3 & 2.70 & 0.33 & 1.19 & 118 & 65 & 60 \\
\hline \multirow{3}{*}{$\begin{array}{l}\text { Soaking } \\
\left(\mathrm{mgKg}^{-1}\right)\end{array}$} & 150 & 2.82 & 0.37 & 1.30 & 123 & 71 & 63 \\
\hline & 250 & 2.89 & 0.39 & 1.32 & 129 & 74 & 65 \\
\hline & 350 & 2.98 & 0.41 & 1.36 & 134 & 75 & 66 \\
\hline \multirow{3}{*}{$\begin{array}{l}\text { Foliar } \\
\left(\mathrm{mgKg}^{-1}\right)\end{array}$} & 150 & 2.58 & 0.26 & 1.06 & 99 & 56 & 49 \\
\hline & 250 & 2.61 & 0.30 & 1.09 & 105 & 59 & 52 \\
\hline & 350 & 2.64 & 0.33 & 1.17 & 109 & 62 & 54 \\
\hline \multicolumn{2}{|c|}{ LSD \%5 Methods } & ns & 0.051 & ns & 3.05 & 0.28 & 3.24 \\
\hline \multicolumn{2}{|c|}{ LSD\% 5 Rates } & ns & 0.057 & ns & 4.00 & 0.31 & 3.62 \\
\hline
\end{tabular}


Table (5): Macro-Micronutrients concentration in rice grains (2007 -2008)

\begin{tabular}{|c|c|c|c|c|c|c|c|}
\hline \multirow[t]{2}{*}{ Treatments } & \multirow{2}{*}{$\begin{array}{c}\mathrm{Zn}+\mathrm{Mn} \\
\quad+\mathrm{Fe}\end{array}$} & \multicolumn{3}{|c|}{$\begin{array}{c}\text { Macronutrients } \\
(\%)\end{array}$} & \multicolumn{3}{|c|}{$\begin{array}{l}\text { Micronutrients } \\
\text { (mgkg-1) }\end{array}$} \\
\hline & & $\mathbf{N}$ & $\mathbf{P}$ & $\mathbf{K}$ & $\mathrm{Fe}$ & Mn & Zn \\
\hline \multicolumn{8}{|c|}{2007} \\
\hline Control & & 0.97 & 0.21 & 0.35 & 29 & 41 & 13 \\
\hline \multirow{3}{*}{$\begin{array}{l}\text { Coating } \\
(\mathrm{g})\end{array}$} & 0.1 & 1.09 & 0.35 & 0.46 & 34 & 46 & 16 \\
\hline & 0.2 & 1.13 & 0.41 & 0.48 & 37 & 49 & 18 \\
\hline & 0.3 & 1.15 & 0.42 & 0.51 & 39 & 52 & 21 \\
\hline \multirow{3}{*}{$\begin{array}{l}\text { Soaking } \\
\left(\mathrm{mgKg}^{-1}\right)\end{array}$} & 150 & 1.34 & 0.46 & 0.61 & 42 & 53 & 23 \\
\hline & 250 & 1.39 & 0.49 & 0.66 & 46 & 56 & 25 \\
\hline & 350 & 1.42 & 0.52 & 0.68 & 48 & 59 & 28 \\
\hline \multirow{3}{*}{$\mid \begin{array}{l}\text { Foliar } \\
\left(\mathbf{m g K g}^{-1}\right)\end{array}$} & 150 & 1.12 & 0.33 & 0.38 & 31 & 43 & 15 \\
\hline & 250 & 1.18 & 0.37 & 0.51 & 36 & 46 & 18 \\
\hline & 350 & 1.22 & 0.41 & 0.55 & 38 & 48 & 20 \\
\hline \multicolumn{8}{|c|}{2008} \\
\hline Control & & 1.02 & 0.26 & 0.38 & 31 & 43 & 14 \\
\hline \multirow{3}{*}{$\begin{array}{l}\text { coating } \\
\text { (g) }\end{array}$} & 0.1 & 1.12 & 0.39 & 0.50 & 35 & 49 & 18 \\
\hline & 0.2 & 1.15 & 0.43 & 0.52 & 39 & 53 & 19 \\
\hline & 0.3 & 1.36 & 0.44 & 0.54 & 42 & 55 & 22 \\
\hline \multirow{3}{*}{$\begin{array}{l}\text { Soaking } \\
\left(\mathrm{mgKg}^{-1}\right)\end{array}$} & 150 & 1.42 & 0.48 & 0.62 & 45 & 58 & 24 \\
\hline & 250 & 1.45 & 0.53 & 0.69 & 49 & 61 & 28 \\
\hline & 350 & 1.52 & 0.56 & 0.71 & 51 & 63 & 31 \\
\hline \multirow{3}{*}{$\begin{array}{l}\text { Foliar } \\
\left(\mathbf{m g K g}^{-1}\right)\end{array}$} & 150 & 1.13 & 0.35 & 0.42 & 33 & 46 & 17 \\
\hline & 250 & 1.18 & 0.39 & 0.57 & 38 & 49 & 20 \\
\hline & 350 & 1.20 & 0.42 & 0.59 & 40 & 51 & 22 \\
\hline \multicolumn{2}{|c|}{ LSD \%5 Methods } & ns & 0.028 & ns & ns & ns & 0.16 \\
\hline \multicolumn{2}{|c|}{ LSD\% 5 Rates } & ns & 0.031 & ns & ns & ns & 0.18 \\
\hline
\end{tabular}

Nitrogen, phosphorus and potassium concentrations in rice as affected by different methods and rates of micronutrients:

Data in Tables (4 \&5) show the effect of different methods and rates of $\mathrm{Fe}, \mathrm{Mn}$ and $\mathrm{Zn}$ chelate on concentration of $\mathrm{N}, \mathrm{P}$ and $\mathrm{K}$ in rice grains and straw. Results revealed that the percentage of $\mathrm{N}$ and $\mathrm{K}$ contents in straw and grains in response to the different applied methods and rates recorded no significant increase, while $\mathrm{P}$ recorded significant increase. The relative increases of $\mathrm{N}$ contents in straw were ranged between $2.36-2.96 \%$ in $1^{\text {st }}$ and $2.41-2.98 \%$ in $2^{\text {nd }}$ season, from $0.18-0.38 \%$ in $1^{\text {st }} 0.21-0.41 \%$ in $2^{\text {nd }}$ season for phosphorus. However, they ranged from $0.99-1.32 \%$ in $1^{\text {st }}$ and $1.02-1.36 \%$ in $2^{\text {nd }}$ season for $\mathrm{K}$. The relative increases of $\mathrm{N}, \mathrm{P}$ and $\mathrm{K}$ contents in grain ranged between $0.97-1.42 \%$ in $1^{\text {st }}$ and $1.02-1.52 \%$ in $2^{\text {nd }}$ season for $\mathrm{N}$, from $0.21-0.52 \%$ in $1^{\text {st }}$ and $0.26-0.56 \% 2^{\text {nd }}$ season for $\mathrm{P}$ and $0.35-0.68 \%$ in $1^{\text {st }}$ and $0.38-0.71 \% 2^{\text {nd }}$ season for $\mathrm{K}$.

Generally the obtained data showed that N, P and K in straw and grains in response to the different applied methods and rates of chelated micronutrients compound exhibited the following order: soaking > coating > foliar for both seasons; compared to control. These findings could be explained due to the role of micronutrients in enhancing the uptake of macronutrients. In this respect, El-Fouly and Fawzi (1996) noted that micronutrients application led to encourage the growth of root, which in turn take up higher contents of $\mathrm{N}, \mathrm{P}$ and $\mathrm{K}$ and finally being reflected on the yield. 


\section{Shaban, K. A. H. et al.}

Also, the obtained results are in harmony with those reported by Shams El-Din (1993) who found that the $\mathrm{N}$ and $\mathrm{P}$ concentrations increased in wheat grains and straw due to application of $\mathrm{Zn}, \mathrm{Mn}$, and Fe, applied as foliar spray, seed coating and seed soaking. Moreover, Yurshevich et al. (1985) found that $\mathrm{Zn}$ application to barley, increased $\mathrm{N}$, and $\mathrm{P}$ content but reduced $\mathrm{K}$ content in grain and straw.

\section{Nutrients uptake in straw and grains of rice plant}

Statistical analysis in Table (6\&7) showed that the various methods and rates of application of a mixture chelated $\mathrm{Fe}, \mathrm{Mn}$ and $\mathrm{Zn}$ exhibit significant response with $\mathrm{Fe}, \mathrm{Zn}, \mathrm{N}$ and $\mathrm{P}$ uptake in straw yield for two mentioned seasons. As for $\mathrm{K}$, this finding was true with the methods of application only. Similarly, Mn gave non significant effect with the methods of application besides the rates.

Table (6): Macro-Micronutrients uptake in rice straw (2007 - 2008)

\begin{tabular}{|c|c|c|c|c|c|c|c|}
\hline \multirow[t]{2}{*}{ Treatments } & \multirow{2}{*}{$\mathrm{Zn}+\mathrm{Mn}+\mathrm{Fe}$} & \multicolumn{3}{|c|}{$\begin{array}{l}\text { Macronutrients } \\
\left(\mathrm{kg} \mathrm{fed}^{-1}\right)\end{array}$} & \multicolumn{3}{|c|}{$\begin{array}{l}\text { Micronutrients } \\
\left(\mathrm{kg} \mathrm{fed}^{-1}\right)\end{array}$} \\
\hline & & $\mathbf{N}$ & $\mathbf{P}$ & $\mathrm{K}$ & $\mathrm{Fe}$ & Mn & $\mathrm{Zn}$ \\
\hline \multicolumn{8}{|c|}{2007} \\
\hline Control & & 9.79 & 2.12 & 3.53 & 29 & 41 & 13 \\
\hline \multirow{3}{*}{ Coating } & $0.1(\mathrm{~g})$ & 21.66 & 6.95 & 9.14 & 67 & 91 & 32 \\
\hline & $0.2(\mathrm{~g})$ & 24.48 & 8.88 & 10.40 & 80 & 106 & 39 \\
\hline & $0.3(\mathrm{~g})$ & 25.25 & 9.22 & 11.20 & 85 & 114 & 46 \\
\hline \multirow{3}{*}{ Soaking } & 150(ppm) & 35.83 & 12.30 & 16.31 & 112 & 142 & 61 \\
\hline & 250(ppm) & 38.07 & 13.42 & 18.06 & 126 & 154 & 68 \\
\hline & $350(\mathrm{ppm})$ & 39.99 & 14.64 & 19.15 & 135 & 166 & 79 \\
\hline \multirow{3}{*}{ Foliar } & 150 (ppm) & 23.13 & 6.81 & 7.85 & 64 & 89 & 31 \\
\hline & $250(\mathrm{ppm})$ & 25.13 & 7.88 & 10.86 & 77 & 98 & 38 \\
\hline & $350(\mathrm{ppm})$ & 26.13 & 8.78 & 11.78 & 81 & 103 & 43 \\
\hline \multicolumn{8}{|c|}{2008} \\
\hline Control & & 11.42 & 2.91 & 4.26 & 35 & 48 & 61 \\
\hline \multirow{3}{*}{ Coating } & $0.1(\mathrm{~g})$ & 23.30 & 8.12 & 10.41 & 73 & 102 & 37 \\
\hline & $0.2(\mathrm{~g})$ & 25.01 & 9.32 & 11.31 & 85 & 115 & 41 \\
\hline & $0.3(\mathrm{~g})$ & 29.87 & 9.67 & 11.86 & 92 & 121 & 48 \\
\hline \multirow{3}{*}{ Soaking } & $150(\mathrm{ppm})$ & 38.52 & 13.02 & 16.82 & 122 & 157 & 65 \\
\hline & $250(\mathrm{ppm})$ & 41.93 & 15.32 & 19.95 & 142 & 176 & 81 \\
\hline & $350(\mathrm{ppm})$ & 44.38 & 16.35 & 20.73 & 149 & 184 & 90 \\
\hline \multirow{3}{*}{ Foliar } & 150(ppm) & 23.96 & 7.42 & 8.91 & 70 & 97 & 36 \\
\hline & $250(\mathrm{ppm})$ & 25.32 & 8.36 & 12.23 & 81 & 105 & 43 \\
\hline & $350(\mathrm{ppm})$ & 25.85 & 9.05 & 12.71 & 86 & 110 & 47 \\
\hline \multicolumn{2}{|c|}{ LSD \% 5 Methods } & 0.29 & 0.13 & 1.89 & 2.11 & ns & 0.32 \\
\hline \multicolumn{2}{|l|}{ LSD\% 5 Rate } & 0.55 & 0.10 & ns & 2.38 & ns & 0.36 \\
\hline
\end{tabular}

In the case of grains, the results disclosed that $\mathrm{Mn}, \mathrm{Zn}, \mathrm{N}$ and $\mathrm{P}$ uptake is significantly affected by the different methods application and rates of chelated micronutrients. Nonetheless, Fe showed such trend with the rates of application only. Moreover, $\mathrm{K}$ recorded no significant effect due to either application methods or rates, while Fe gave the same trend with application methods only. The data indicates that the efficiency of applying micronutrients by seed soaking method in correcting micronutrients deficiency that improve nutrient balance, use of NPK fertilizers and yield in turn. It can be noted that micronutrient treatments caused the highest 
increase in macro and micronutrients. In this respect, Wang and Song (2005) noted that soaking rice seeds in zinc solution at a concentration of $0.3 \mathrm{mg} / \mathrm{L}$ led to increase in germination rate, seed activity and membrane penetration of seeds. Furthermore, Attia et al. (2007) revealed that applying micronutrients by seed soaking method was very effective in improving the uptake of macro and micronutrients in grain yield of rice plant.

It is worth mentioning that treated rice grains with soaking method at the rate of $350 \mathrm{mgkg}^{-1}$ from a mixture chelated compound achieved the best results. In other words, soaking method was more suitable for rice. It is worthy also to note that $\mathrm{pH}$ and $\mathrm{EC}$ of the soil were dropped after harvesting; $\mathrm{pH}$ was dropped from 8.29 to7.93 and EC from 17.36 to 12.36.

Table (7): Macro-Micronutrients uptake in rice grain (2007 - 2008)

\begin{tabular}{|c|c|c|c|c|c|c|c|}
\hline \multirow[t]{2}{*}{ Treatments } & \multirow[t]{2}{*}{$\mathrm{Zn}+\mathrm{Mn}+\mathrm{Fe}$} & \multicolumn{3}{|c|}{$\begin{array}{l}\text { Macronutrients } \\
\left(\mathrm{kg} \mathrm{fed}^{-1}\right)\end{array}$} & \multicolumn{3}{|c|}{$\begin{array}{l}\text { Micronutrients } \\
\left(\mathrm{kg} \mathrm{fed}^{-1}\right)\end{array}$} \\
\hline & & $\mathbf{N}$ & $\mathbf{P}$ & $\mathrm{K}$ & $\mathrm{Fe}$ & Mn & Zn \\
\hline \multicolumn{8}{|c|}{2007} \\
\hline Control & & 37.42 & 2.85 & 15.70 & 141 & 77 & 54 \\
\hline \multirow{3}{*}{ Coating } & $0.1(\mathrm{~g})$ & 60.55 & 5.86 & 25.35 & 218 & 124 & 96 \\
\hline & $0.2(\mathrm{~g})$ & 64.91 & 7.16 & 26.52 & 242 & 141 & 108 \\
\hline & $0.3(\mathrm{~g})$ & 66.34 & 7.70 & 29.10 & 273 & 154 & 114 \\
\hline \multirow{3}{*}{ Soaking } & $150(\mathrm{ppm})$ & 86.42 & 10.30 & 39.31 & 368 & 206 & 159 \\
\hline & $250(\mathrm{ppm})$ & 92.14 & 11.40 & 42.00 & 410 & 225 & 186 \\
\hline & $350(\mathrm{ppm})$ & 97.32 & 12.50 & 43.40 & 424 & 230 & 194 \\
\hline \multirow{3}{*}{ Foliar } & $150(\mathrm{ppm})$ & 58.28 & 5.45 & 24.87 & 227 & 126 & 101 \\
\hline & $250(\mathrm{ppm})$ & 65.10 & 7.16 & 29.73 & 251 & 140 & 120 \\
\hline & $350(\mathrm{ppm})$ & 69.10 & 8.00 & 31.17 & 277 & 149 & 131 \\
\hline & \multicolumn{7}{|c|}{2008} \\
\hline \multirow{2}{*}{ Control } & & 40.10 & 3.49 & 16.96 & 156 & 85 & 43 \\
\hline & $0.1(\mathrm{~g})$ & 61.57 & 6.61 & 26.42 & 233 & 130 & 104 \\
\hline \multirow[t]{2}{*}{ Coating } & $0.2(\mathrm{~g})$ & 66.43 & 7.89 & 28.61 & 266 & 149 & 127 \\
\hline & $0.3(\mathrm{~g})$ & 67.47 & 8.25 & 29.74 & 295 & 162 & 150 \\
\hline \multirow{3}{*}{ Soaking } & $150(\mathrm{ppm})$ & 88.35 & 11.59 & 40.73 & 385 & 222 & 197 \\
\hline & $250(\mathrm{ppm})$ & 94.45 & 12.75 & 43.14 & 421 & 242 & 212 \\
\hline & $350(\mathrm{ppm})$ & 120.00 & 15.37 & 51.00 & 502 & 281 & 247 \\
\hline \multirow{3}{*}{ Foliar } & $150(\mathrm{ppm})$ & 61.35 & 6.18 & 25.21 & 235 & 133 & 117 \\
\hline & $250(\mathrm{ppm})$ & 67.05 & 7.71 & 28.00 & 270 & 152 & 133 \\
\hline & $350(\mathrm{ppm})$ & 71.54 & 8.94 & 31.71 & 295 & 168 & 146 \\
\hline \multicolumn{2}{|c|}{ LSD \% 5 Methods } & 0.094 & 0.162 & ns & ns & 2.48 & 0.46 \\
\hline \multicolumn{2}{|l|}{ LSD\% 5 Rate } & 0.105 & 0.181 & ns & 31.32 & 2.44 & 0.44 \\
\hline
\end{tabular}

\section{Conclusion}

In the light of the obtained results, it can be concluded that using of soaking method application at a rate of $350 \mathrm{mg} / \mathrm{Kg}^{-1}$ from a chelated compound mixture of micronutrients namely $\mathrm{Fe}, \mathrm{Mn}$ and $\mathrm{Zn}$ could improve the yield of rice plant and its component in a newly reclaimed saline soil. 


\section{REFERENCES}

Alam, S. M.; Ansari, R.; S. M. Mujtaba; and Sh. Aisha (2001). Saline lands and rice. NIA, Tandojam, Pakistan. Apr., 23 - 29.

Amin,M .A. A. ;M. M. Badr, T. A. Abou El-Defa and Nadia, O. Monged (1998). Application of $\mathrm{Fe}, \mathrm{Mn}$ and $\mathrm{Zn}$ by different methods and their effects on yield and mineral composition of maize .J. Agric. Sci. Mansoura Univ., 23(7):3539-3547.

Anand, S. (1993). Iron, Zinc and manganese nutrition of wetland rice (Oryza Sativa L) on gypsum amended sodic soil. J. Plant and Soil. (1): 477 480.

Attia, M. A. ; H. G. Abou El-Fotoh ; S.M. Allam and E. M. Eglal (2007) . Effect of soaking seeds in a mixture of chelated $\mathrm{Fe}, \mathrm{Mn}$ and $\mathrm{Zn}$ solution with agar as a carrier, on the yield and yield components of rice (Oryza Stiva, L.). J. Agric. Sci. Mansoura. Univ., 32 (8): 6985- 6990.

Badr, M.M.; S.A. AbdEl-Rehim, T.A. AbouEl-Defan and Nadia, O. Monged (1998).Effect of different methods of some micronutrients application on yield,chemical content and some fiber properties of cotton Giza77C.V. Egypt. J. Appl. Sci.,13(7):365-373

Black, C. A.; D. D. Evans; J. L. White; L. E. Enminger and F. F. Clark (1965). "Methods of Soil Analysis." Soil Science Society of American Inc. Publisher, Madison, Wisconsin, U.S.A.

Chapman, H. D. and P. F. Pratt (1961). "Methods of Analysis for Soils, Plants and Water. Agric. Y. C . Publ. Univ., of California, Riverside, USA.

El-Bordiny, M. M. and C. Y. El-Dewiny (2008). Effect of some properties on micronutrients availability. J.Appl.Sci.Res.,4 (11): 1569 - 1573.

El-Fouly, M.and A. A. Fawzi (1996). Fertilizer Use in the Near East Agriculture Over View. Regional Workshop on Fertilizer use for Sustainable Agriculture. Amman, Jorden 4-6.

El-Fouly, M. M.; M. M. Zeinab and A. S. Zeinab (2001). Micronutrients spray as a tool to increase tolerance of faba bean and wheat plants to salinity. Plant Nutrition. 92 (6): 422- 423.

FAO, (1995). Improvement and Production, Drainage and Salinity. An International Source Book. Paris.

Ghaly, S.; A. O. Osman, and A. Abou-Bakr (1992). The effect of applying micronutrients fertilizer by coating methods on wheat. Fifth Botanical Conference, Sant Catherine, Sinai Egypt. April 28-30.

Imtiaz , B. J.; K. H .Alloway; S. H .Shah; M. Y. Siddiqui; M. A. Memon and P. Khan, (2003). Zinc nutrition of wheat: II - Interaction of zinc with other trace elements. Asian Journal of Plant Science. 2 (2): 156 - 160.

Korayem, A. M. (1993). Effect of zinc fertilization on rice plants and on the population of the rice - root nematoda Hirschmanniella Oryzae. Aczeiger Fur Schadlingsjunde, Pflonzenschwutz, Umweltschutz. 66 (1): 18- 21.

Lindsay, W. L. and W. A. Norvell (1978). Development of DTPA test for zinc, iron, manganese and copper. Soil Sci. Soc. Am. J., 42: 421-429. 
Malakouti, M. J. (2000). Balanced nutrition of wheat: An approach towards self-sufficiency and enhancement of national health. "A compilation of papers". Ministry of Agriculture, Karaj, Iran. 544 pp.

Malakouti, M. J. (2007). Zinc is a neglected element in the life cycle of plants. A review. Middle East. Rus. J. Plant Sci. and Biotech., (1): 1-12.

Mohammad, J. M. (2008). The effect of micronutrients in ensuring efficient use of macronutrients. Turk. J. Agric. for Tarbiat, Modares Univ., (32): 215- 220.

Monged, N. O. and A. Mawardi (1978). Effect of different levels of zinc on some rice varieties. Agric. Res. Rev., Ministry of Agriculture, Cairo. 64.

Sairam, R. K. and A. Tyagi (2004). Physiology and molecular biology of salinity stress tolerance in plants. Current Science. 86 (3): $407-421$.

Shams El-Din, H. A. (1993). Application Methods and Rates of Some Micronutrients on Wheat Plant. Ph.D. Thesis, Fac. Agric., ElMansoura, Univ. Egypt.

Wang, Xiaobo and Song, F. B. (2005). A study on the effect of zinc on germination of rice. Journal of Jilin Agriculture University,27(2):119122.

Yurshevich, A. S.; I. I. Bezlyundaya and T. D. Karpovich (1985). The effect of trace element fertilizer on barley yields on dernopodzolic light loamy soils of Byelorussia. Agrokhimiya.. 7: 81-85. (c.f. Wheat, Barley and Triticale Abst., 3 (4): 3709 - 1986).

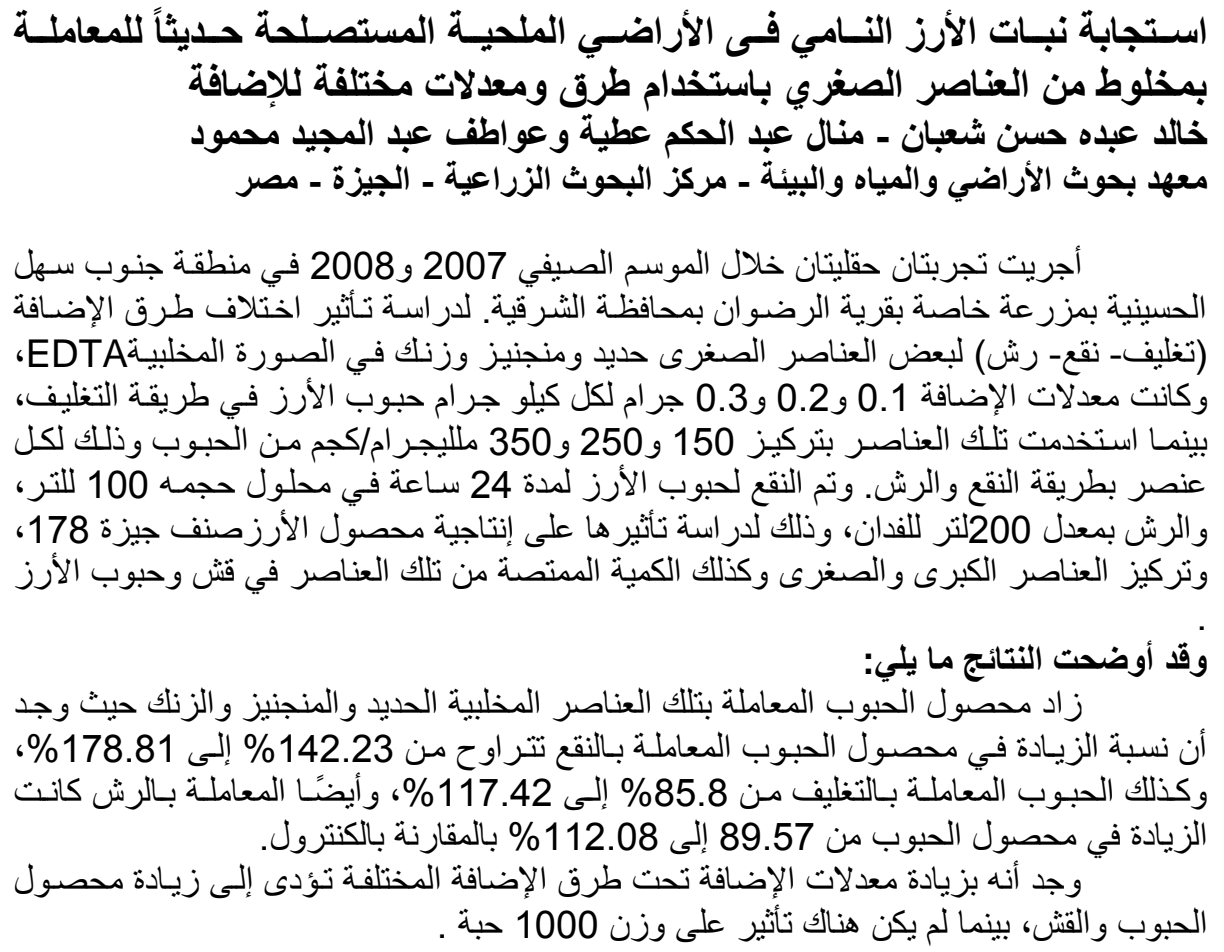




\section{Shaban, K. A. H. et al.}

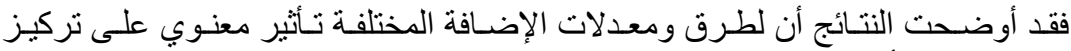

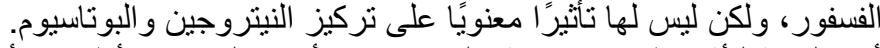

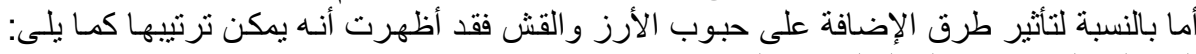

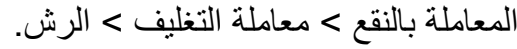

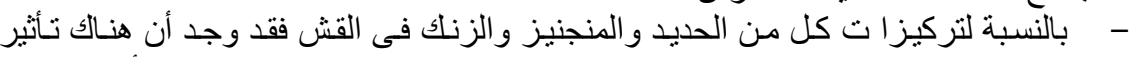

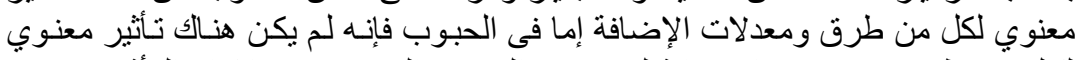

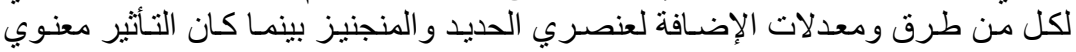
لعنصر الزنك فقط.

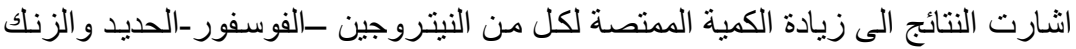

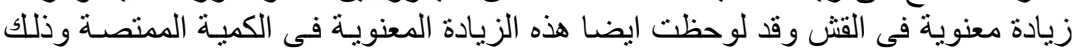

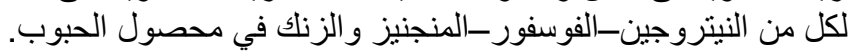

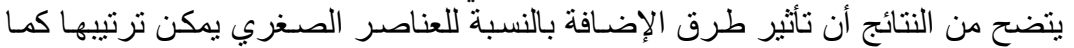

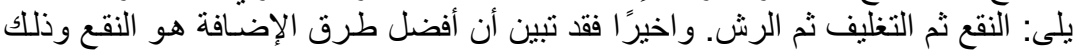

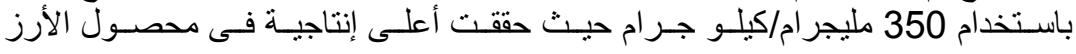

$$
\text { ومحتوياته }
$$

كلية الزراعه - جامعة المنصوره

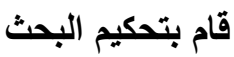
مركز البحوث الزراعيه

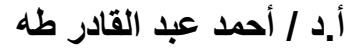
أ.د / أبو بكر الصديق محمد عبدالله 